\title{
ANALISIS POLA PENEMPATAN ASET PEDAGANG
}

\author{
Leonardus Very Yudi Pradana \\ Fakultas Ekonomika dan Bisnis, Universitas Kristen Satya Wacana Salatiga \\ leonardus_very@rocketmail.com \\ Birgitta Dian Saraswati \\ Fakultas Ekonomika dan Bisnis, Universitas Kristen Satya Wacana Salatiga \\ dian.saraswati@staff.uksw.edu
}

\begin{abstract}
Monetary policy does not always go smoothly and effectively because it is influenced by pattern and behavior of society in placing asset. The result of this research by using quota sampling shows that type of monetary asset, e.g. savings on formal monetary institution, becomes more by 74,80\% vendors in Salatiga, then followed by asset in the form of saving in non formal monetary institution, and insurance. This research finds that there is, no vendors place their asset in the form of bond. Meanwhile, in terms of physical asset, placing asset in the form of land becomes priority for almost 30,08\% vendors who prefer doing it. The next physical asset is in the form of building, gold, and cattle. However, as many as $86 \%$ respondents do not know about monetary variable, e.g. interest rate and inflation. For vendors in Salatiga, interest rate is not a consideration in placing asset. Hence, this causes monetary policy by using interest rate as an instrument to control the active circulation becomes ineffective.
\end{abstract}

Keywords: monetary policy, assets placement patter, physical asset

\begin{abstract}
ABSTRAK
Kebijakan moneter tidak selalu berjalan lancar dan efektif karena dipengaruhi oleh pola dan perilaku masyarakat dalam menempatkan aset. Hasil penelitian ini dengan menggunakan quota sampling menunjukkan bahwa jenis aset moneter, misalnya tabungan di lembaga keuangan formal, menjadi lebih disukai oleh $74,80 \%$ pedagang di Salatiga, diikuti oleh aset dalam bentuk tabungan di lembaga keuangan non formal dan asuransi. Penelitian ini menemukan bahwa tidak ada pedagang menempatkan aset mereka dalam bentuk obligasi. Sementara itu, dari segi aset fisik, menempatkan aset dalam bentuk tanah menjadi prioritas bagi hampir 30,08\% vendor yang lebih suka melakukannya. Aset fisik berikutnya adalah dalam bentuk bangunan, emas, dan ternak. Sebanyak $86 \%$ responden tidak tahu tentang variabel moneter, misalnya suku bunga dan inflasi. Bagi pedagang di Salatiga, tingkat suku bunga tidak menjadi pertimbangan dalam menempatkan aset. Oleh karena itu, hal ini menyebabkan kebijakan moneter dengan menggunakan suku bunga sebagai instrumen untuk mengontrol sirkulasi aktif menjadi tidak efektif.
\end{abstract}

Kata kunci: kebijakan moneter, pola penempatan asset, aset fisik 


\section{PENDAHULUAN}

Undang-Undang Bank Indonesia Nomor 23 tahun 1999 menyatakan bahwa tujuan tunggal Bank Indonesia adalah mencapai dan memelihara kestabilan nilai Rupiah. Stabilitas terhadap harga barang dan jasa tercermin dari tingkat inflasi dan stabilitas terhadap nilai mata uang yang tercermin dalam nilai tukar. Untuk mencapai kestabilan inflasi, Bank Sentral memiliki kerangka kerja kebijakan moneter yang dinamakan Inflation Targeting Framework (ITF). Kerangka tersebut menjadikan dasar bagi Bank Indonesia (BI) dalam mengumumkan sasaran inflasi kepada publik dan kebijakan moneter diarahkan untuk mencapai sasaran inflasi yang ditargetkan, sehingga diharapkan kestabilan inflasi dapat tercapai baik melalui sektor moneter maupun fiskal/riil. Instrumen yang dipakai untuk mencapai sasaran inflasi tersebut adalah melalui penetapan suku bunga kebijakan (BI rate) yang diharapkan memengaruhi suku bunga pasar uang dan suku bunga deposito dan suku bunga kredit perbankan.

Otoritas Bank Sentral berada pada sektor moneter sehingga perlu mekanisme khusus agar kebijakan moneter yang menggunakan instrumen penetapan suku bunga dapat ditransmisikan dari sektor moneter ke sektor riil/fiskal, yang disebut sebagai mekanisme transmisi kebijakan moneter. Dengan adanya mekanisme transmisi kebijakan moneter, maka kebijakan moneter dapat berpengaruh pula terhadap berbagai pelaku ekonomi di sektor riil sehingga berdampak pada pertumbuhan ekonomi masyarakat. Mekanisme tersebut terjadi melalui interaksi antara Bank Sentral, perbankan dan sektor keuangan, serta para pelaku ekonomi dalam berbagai aktivitas di sektor ekonomi riil. Pada tahap pertama kebijakan moneter ditransmisikan melalui sektor perbankan dan sektor keuangan, kemudian tahap intermediasi melalui bank umum yang merupakan media dalam transmisi kebijakan moneter terhadap para pelaku ekonomi dalam berbagai aktivitas di sektor ekonomi riil (Pohan 2008). Perubahan BI Rate memengaruhi inflasi melalui berbagai jalur, di antaranya jalur suku bunga, jalur kredit, jalur nilai tukar, jalur harga aset dan jalur ekspektasi.

Keefektifan mekanisme transmisi kebijakan moneter tersebut tidak bisa dilepaskan dari perilaku penempatan aset oleh masyarakat. Apabila masyarakat cenderung menempatkan asetnya dalam bentuk keuangan ataupun perbankan, maka transmisi kebijakan moneter tersebut menjadi lebih efektif. Rendra et al. (2002) menginvestigasi peran dan pengaruh mekanisme transmisi kebijakan moneter jalur harga aset di Indonesia, menemukan bukti bahwa sedikit masyarakat yang menempatkan asetnya dalam bentuk portofolio aset finansial. Oleh karena itu, mekanisme transmisi kebijakan moneter mengalami kegagalan untuk dapat ditransmisikan terhadap inflasi. Hasil studi yang dilakukan Bank Indoensia (2004) memperlihatkan bahwa terjadinya transmisi perubahan suku bunga terhadap sektor riil melalui perubahan harga aset, meskipun tidak terlalu kuat. Hal ini dikarenakan masyarakat lebih meminati penempatan aset dalam bentuk fisik dengan alasan keamanan. Penelitian serupa yang dilakukan oleh Koivu (2012) menunjukkan bahwa kebijakan moneter memiliki impact terhadap harga aset maupun perumahan (housing) yang selanjutnya berpengaruh positif terhadap pola konsumsi 
rumah tangga di Cina. Namun demikian, pengaruhnya begitu lemah karena sedikit masyarakat yang memiliki aset berbentuk saham. Sedangkan di Rusia, penelitian oleh Andresen (2005) yang ingin melihat dan memahami secara sosial perilaku masyarakat yang menempatkan aset dalam bentuk yang tidak menguntungkan, mendapati hasil bahwa adanya ketidakpercayaan masyarakat yang menyebabkan sulitnya untuk menempatkan aset dalam bentuk finansial.

Dari keempat penelitian tersebut menampilkan bahwa transmisi kebijakan moneter belum tentu berjalan mulus dan efektif dikarenakan ketergantungan oleh pola penempatan aset masyarakat. Dari alasan tersebut, maka penelitian ini mencermati dan menganalisis pola penempatan aset di masyarakat di Salatiga. Sebagai bagian dari provinsi di Jawa Tengah, Salatiga merupakan kota dimana yang cukup banyak penduduknya yang memiliki mata pencaharian sebagai pedagang. Hal ini ditunjukkan dengan adanya distribusi penduduk di Kota Salatiga berdasarkan mata pencaharian yang dapat dilihat pada Tabel 1 profesi pedagang menempati peringkat ketiga berdasarkan persentase distribusinya.

Tabel 1

Jumlah Penduduk Kota Salatiga Berdasarkan Pekerjaan Tahun 2011

\begin{tabular}{lrr}
\hline \multicolumn{1}{c}{ Lapangan Pekerjaan } & Jumlah & Distribusi \\
\hline Petani Sendiri & 4.021 & $3,17 \%$ \\
Buruh Tani & 4.611 & $3,63 \%$ \\
Nelayan & 0 & $0,00 \%$ \\
Pengusaha & 5.095 & $4,01 \%$ \\
Buruh Industri & 20.653 & $16,27 \%$ \\
Pedagang & 11.205 & $8,83 \%$ \\
Buruh Bangunan & 8.962 & $7,06 \%$ \\
Transportasi & 5.355 & $4,22 \%$ \\
Pegawai Negeri, TNI / Polri & 10.191 & $8,03 \%$ \\
Pensiunan & 5.498 & $4,33 \%$ \\
Lain-lain & 51.377 & $40,46 \%$ \\
Jumlah & $\mathbf{1 2 6 . 9 6 8}$ & $\mathbf{1 0 0 \%}$ \\
\hline Sumber: Salatiga Dalam Angka, 2012 & &
\end{tabular}

Sumber: Salatiga Dalam Angka, 2012

Dari Tabel 1 diatas menunjukkan bahwa cukup banyak masyarakat di Kota Salatiga memiliki profesi sebagai pedagang. Pedagang menempati urutan ke 3 sebagai profesi yang dimiliki oleh masyarakat. Besarnya masyarakat yang berprofesi sebagai pedagang memiliki dampak pada struktur perekonomian di Kota Salatiga. Sektor perdagangan, hotel dan restoran berada di urutan kedua sebagai penyumbang PDRB terbesar di Kota Salatiga yang ditunjukkan oleh Tabel 2. 
Tabel 2

PDRB Kota Salatiga Tahun 2011 atas Dasar Harga Konstan Tahun 2000 Menurut Lapangan Usaha (Juta Rupiah)

\begin{tabular}{lrrr}
\hline \multicolumn{1}{c}{ Lapangan Usaha } & \multicolumn{2}{c}{$\mathbf{2 0 1 1}$} \\
\cline { 2 - 4 } & \multicolumn{1}{c}{ Jumlah } & \% & Rangking \\
\hline 1. Pertanian & $52.565,95$ & 5,46 & 7 \\
2. Pertambangan \& Penggalian & 527,69 & 0,05 & 9 \\
3. Industri Pengolahan & $190.657,34$ & 19,79 & 1 \\
4. Listrik, Gas \& Air Bersih & $49.882,67$ & 5,18 & 8 \\
5. Bangunan & $61.441,16$ & 6,38 & 6 \\
6. Perdagangan Hotel \& Restoran & $187.607,13$ & 19,47 & 2 \\
7. Pengangkutan \& Komunikasi & $148.326,29$ & 15,39 & 4 \\
8. Keu. Persewaan, \& Jasa Perusahaan & $96.811,17$ & 10,05 & 5 \\
9. Jasa-Jasa & $175.667,94$ & 18,23 & 3 \\
\hline \multicolumn{1}{c}{ PDRB } & $\mathbf{9 6 3 . 4 8 7 , 3 4}$ & $\mathbf{1 0 0}$ & \\
\hline
\end{tabular}

Sumber: Salatiga Dalam Angka, 2012

Dengan melihat besarnya peran sektor perdagangan terhadap struktur perekonomian di kota Salatiga, maka diharapkan pola penempatan aset oleh pedagang Salatiga mampu menjadi representasi pola perilaku penempatan aset masyarakat Kota Salatiga pada umumnya. Tujuan dalam penelitian ini adalah mengidentifikasi dan menganalisis pola perilaku penempatan aset pedagang di Kota Salatiga, mengidentifikasi pengetahuan masyarakat akan variabel moneter seperti inflasi dan suku bunga.

\section{KAJIAN PUSTAKA}

\section{Pengertian Kebijakan Moneter}

Kebijakan moneter adalah tindakan yang dilakukan oleh otoritas moneter (bank sentral) untuk memengaruhi jumlah uang yang beredar dan kredit yang pada gilirannya akan memengaruhi kegiatan ekonomi masyarakat. Ani (2009) menyatakan bahwa kebijakan moneter adalah semua tindakan pemerintah untuk mengendalikan jalannya kehidupan ekonomi nasional kearah yang diinginkan melalui pengendalian jumlah uang yang beredar $\left(M_{S}\right)$.

\section{Jenis-Jenis Kebijakan Moneter}

\section{Operasi Pasar Terbuka (OPT)}

Operasi pasar terbuka adalah kegiatan transaksi di pasar uang yang dilakukan oleh BI dengan bank dan pihak lain dalam rangka pengendalian moneter melalui instrumen jumlah uang beredar. Jenis kegiatan operasi pasar perbuka yaitu penerbitan Sertifikat Bank Indonesia (SBI), jual beli surat berharga dalam rupiah, penyediaan fasilitas simpanan BI dalam Rupiah dan jual beli valas. 


\section{Cadangan Wajib Minimum (Reserve Requirement)}

Cadangan wajib minimum merupakan batasan minimum dana yang harus selalu tersedia pada saldo giro setiap bank pada Bank Indonesia yang saat ini sebesar 5 persen yang berlaku sejak April 1997. BI mengendalikan jumlah uang beredar melalui penetapan rasio (batasan) cadangan wajib minimum tersebut. Apabila BI ingin mengurangi jumlah uang beredar maka BI akan menaikkan cadangan wajib minimum, dan begitu pula sebaliknya.

\section{Politik Diskonto (Discount Policy)}

Kebijakan yang dilakukan oleh bank sentral untuk menambah atau mengurangi jumlah uang beredar melalui suku bunga bank. Apabila bank sentral menaikkan suku bunga, diharapkan perilaku masyarakat agar tidak melakukan kredit/peminjaman uang dari bank, dan lebih preferen pada menabung di bank.

\section{Persuasi Moral (Moral Suasion)}

Kebijakan ini dilakukan oleh BI dengan meminta atau menghimbau perbankan untuk selalu mempertimbangkan kondisi makro ekonomi maupun mikro ekonomi masing-masing bank dalam menyusun rencana ekspansi kredit yang realistis. Kebijakan persuasi moral mendorong perbankan agar menerapkan prinsip kehati-hatian dalam memberikan kredit tidak semata-mata hanya mencari keuntungan belaka secara bebas.

\section{Kebijakan Moneter}

Kebijakan moneter bertujuan dalam menjaga kestabilan ekonomi yang dapat diukur dengan kesempatan kerja, kestabilan harga serta neraca pembayaran internasional yang seimbang (Nopirin 2000). Kebijakan moneter tidak berdiri sendiri dalam perannya terhadap perekonomian (Pohan 2008), namun bersinergi dengan kebijakan makro lainnya seperti kebijakan fiskal, Kebijakan sektoral dan kebijakan lainnya. Semuanya mengarah pada pencapaian tujuan akhir, yakni kesejahteraan sosial masyarakat atau social welfare. Alur dalam kerangka kebijakan moneter dijelaskan melalui gambar 1 berikut ini:

\begin{tabular}{|c|c|c|c|}
\hline $\begin{array}{l}\text { Tools of The } \\
\text { CentralBank }\end{array}$ & $\begin{array}{c}\text { Operating } \\
\text { Target }\end{array}$ & $\begin{array}{c}\text { Intermediate } \\
\text { Target }\end{array}$ & Goals \\
\hline $\begin{array}{l}\text { - Operasi Pasar } \\
\text { Terbuka } \\
\text { - Cadangan } \\
\text { Wajib } \\
\text { Minimum } \\
\text { - Fasilitas } \\
\text { Diskonto }\end{array}$ & $\begin{array}{l}\text { - Jumlah } \\
\text { Uang } \\
\text { Beredar } \\
\text { (M0) } \\
\text { - Suku Bunga } \\
\text { BI rate } \\
\text { (jangka } \\
\text { Pendek) }\end{array}$ & $\begin{array}{l}\text { - Agregat } \\
\text { Moneter } \\
\text { (M1,M2,M3) } \\
\text { - Suku bunga } \\
\text { (jangka } \\
\text { pendek dan } \\
\text { jangka } \\
\text { panjang) }\end{array}$ & $\begin{array}{l}\text { - Stabilitas Harga } \\
\text { - Pertumbuhan } \\
\text { Ekonomi } \\
\text { - Tingkat } \\
\text { Pengangguran }\end{array}$ \\
\hline
\end{tabular}

Gambar 1

Kerangka Kebijakan Moneter 
Dalam pelaksanaanya, kebijakan moneter memiliki kerangka yang terdiri dari Tools atau instrumen yang dipakai oleh bank sentral, target pelaksanaan (operating target), target antara (intermediate target) dan tujuan (goals). Tools yang dipakai oleh Bank Indonesia dalam melaksanakan kebijakan moneter yakni cadangan Cadangan Wajib Minimum (Reserve Requirement), Kebijakan Diskonto dan Operasi pasar terbuka (Open Market Operation). Dengan instrumen tersebut, diharapkan mampu memengaruhi variabel seperti suku bunga dan jumlah uang beredar (Operating Target). Melalui variabel tersebut, nantinya akan mengarahkan atau membimbing kebijakan moneter agar sesuai dengan tujuan yang ingin dicapai.

Namun sebelum tercapainya goals, terdapat indikator yaitu Intermediate Target yang nantinya akan menunjukkan sampai sejauh mana goals akan dapat tercapai sesuai dengan target yang ditetapkan. Dengan tercapainya target antara maka akan lebih mudah dalam mencapai tujuan yang ingin dicapai, karena di masa depan akan tercapai atau tidaknya tujuan kebijakan moneter diindikasikan oleh tercapai atau tidaknya Intermediate Target. Intermediate Target yang dilakukan oleh Bank Indonesia untuk mencapai tujuan stabilisasi harga (inflasi) menggunakan acuan nominal anchor yaitu Inflation Targeting Framefork sebagai target antara yang menjadi acuan yang ditetapkan oleh Bank Indonesia untuk mencapai target stabilitas harga (inflasi) yang ditetapkan dalam tujuan kebijakan moneter.

Target kebijakan moneter berkaitan erat dengan tujuan kebijakan makro ekonomi yakni, stabilitas harga, tingkat pengangguran yang rendah, pertumbuhan ekonomi dan lain-lain. Setiap variabel yang menjadi target kebijakan moneter tersebut memiliki korelasi yang bersifat kontradiktif. Untuk itu dalam menetapkan kebijakan moneter, Bank Indonesia dihadapkan pada dua pilihan (Pohan 2008). Pertama Bank Indonesia dapat memilih satu target atau sasaran dan mengabaikan sasaran yang lain. Kedua Bank Indonesia dapat memilih pencapaian semua sasaran secara serempak, namun tidak secara optimal.

\section{Mekanisme Transmisi Kebijakan Moneter}

Dalam mekanisme transmisi kebijakan moneter, ada 2 pendekatan atau model dalam menjelaskan kebijakan moneter dalam memengaruhi ekonomi riil, yaitu ReduceForm dan Model struktural (structural model). Dalam pendekatan Reduce-Form yang dianut oleh aliran monetarist tidak menggambarkan secara jelas bagaimana uang beredar memengaruhi pengeluaran agregat (output). Dalam pandangan ini, pengaruh perubahan jumlah uang beredar (M) terhadap pengeluaran agregat atau output (Y) di dalam perekonomian tidak dapat dilihat bagaimana bekerjanya, karena dalam pandangan ini percaya adanya invisible hand. Pandangan ini percaya adanya hubungan kausal, dimana apabila M berubah, maka akan berpengaruh pada perubahan Y (Mishkin 2004).

Dalam pandangan model struktural yang dianut oleh aliran keynesian, menjelaskan bagaimana perekonomian bekerja dengan menggunakan sekumpulan 
persamaan yang menunjukkan perilaku perusahaan dan konsumen dalam banyak sektor dalam perekonomian (Mishkin 2004). Kebijakan moneter dapat berpengaruh terhadap perekonomian melalui rangkaian variabel yang saling berpengaruh secara sistematis dengan berbagai jalur. Menurut Mishkin, mekanisme transmisi kebijakan moneter dibagi menjadi beberapa jalur yaitu: Jalur Suku Bunga Tradisional (Traditional Interest-Rate Channels), Jalur Harga Aset Lainnya (Other Asset Price Channels), meliputi pengaruh kurs terhadap Ekspor bersih (Exchange Rate Effect On Net Export), Teori Tobin's q (Tobin's $q$ Theory) dan pengaruh kekayaan (Wealth Effects) dan pandangan Kredit (Credit View), meliputi jalur Kredit Bank (Bank Lending Channel), Jalur Neraca (Balance Sheet Channel), Jalur Arus Kas (Cash Flow Channel), Jalur Tingkat Harga yang Tidak Terantisipasi (Unanticipated Price Level Channel) dan Pengaruh Likuiditas Rumah Tangga (Household Liquidity Effect).

Jalur likuiditas rumah tangga, kebijakan moneter baik ekspansif maupun kontraktif diharapkan mampu memengaruhi sektor riil sehingga akan berpengaruh pada kesejahteraan (welfare) masyarakat. Apabila dalam suatu kebijakan moneter yang ekspansif, maka jumlah uang beredar (money supply) ditambah oleh Bank Indonesia dengan membeli Sertifikat Bank Indonesia (SBI) yang dimiliki oleh bank umum maupun masyarakat. Dampak dari hal tersebut, maka tingkat bunga acuan SBI menjadi turun karena bertambahnya jumlah uang beredar.

Menurunnya tingkat bunga acuan SBI memiliki dampak pada sektor kredit perbankan yaitu biaya pengembalian dana kredit (pinjaman) menjadi lebih kecil dan investasi pun menjadi meningkat. Sementara itu, dalam model aset portofolio Capital Aset Pricing Model (CAPM) atau model penilaian aset modal, dimana adanya peran tingkat bunga SBI sebagai faktor yang memengaruhi tingkat return yang diperoleh dari suatu aset yang diinvestasikan dalam bentuk saham. Tingkat bunga SBI yang turun akan berpengaruh pada meningkatnnya tingkat return yang diperoleh dari aset portofolio, sehingga investor tertarik untuk menanamkan modalnya dalam bentuk aset portofolio tersebut, karena itulah maka harga saham portofolio ikut meningkat pula.

Tingkat return yang diperoleh semakin meningkat akibat dari penurunan tingkat bunga SBI, maka kesejahteraan masyarakat akan meningkat pula. Return tersebut merupakan pendapatan yang diperoleh sebagai imbalan telah menanamkan modalnya dengan membeli saham suatu perusahaan. Pengaruh tingkat bunga SBI terhadap harga aset (Price of Equity) di luar model aset portofolio CAPM ditentukan oleh jenis aset yang dimiliki oleh masyarakat. Ketika aset masyarakat berupa aset finansial, maka memang tingkat bunga SBI akan berpengaruh, namun bagaimana apabila sebagian besar (mayoritas) masyarakat menempatkan asetnya dalam bentuk aset fisik (hoarding) seperti emas, tanah, ternak dan lain-lain. Tentunya tidak seperti aset finansial yang berubah secara elastis akibat perubahan tingkat bunga SBI yang dapat dijelaskan dengan model aset portofolio CAPM. 


\section{Hubungan Penempatan Aset dalam Efektivitas Kebijakan Moneter}

Kerangka kebijakan moneter diharapkan dapat mencapai tujuan akhir dalam sektor riil, untuk itu diperlukan mekanisme transmisi kebijakan moneter, agar kebijakan moneter ekspansif ataupun kontraktif yang ditetapkan oleh Bank Indonesia dapat berjalan efektif dalam memengaruhi sektor riil seperti yang ditunjukkan pada Gambar 2. Salah satu jalur dalam mekanisme transmisi kebijakan moneter adalah melalui jalur likuiditas rumah tangga. Melalui jalur likuiditas rumah tangga kebijakan moneter memengaruhi nilai aset yang dimiliki oleh masyarakat rumah tangga yang kemudian memengaruhi konsumsi masyarakat rumah tangga tersebut terhadap barang tahan lama dan pengeluaran perumahan sehingga pada akhirnya ikut berpengaruh pula terhadap output agregat (Y). Melalui jalur tersebut pengaruh kebijakan moneter ditentukan oleh pola penempatan aset yang dilakukan oleh masyarakat. Sehingga pola penempatan aset masyarakat ikut berpengaruh pula terhadap efektivitas kerangka kebijakan moneter dalam mencapai tujuan akhir dalam sektor riil.

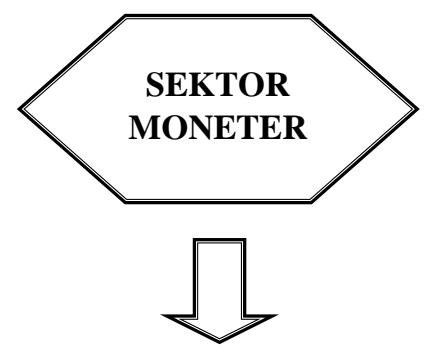

Kebijakan Moneter
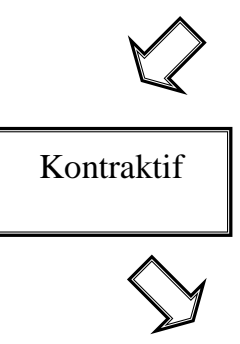

Ekspansif

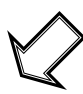

Pola

Penempatan Aset Masyarakat

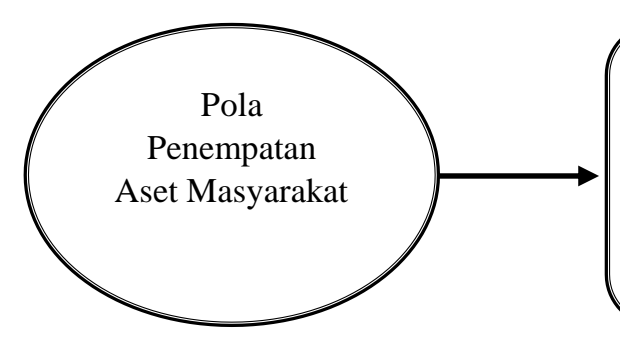

Mekanisme Transmisi Kebijakan Moneter :

Jalur Likuiditas Rumah Tangga

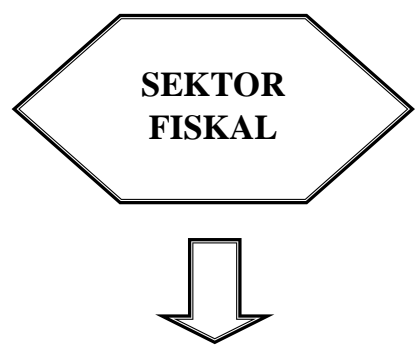

Kebijkan Fiskal

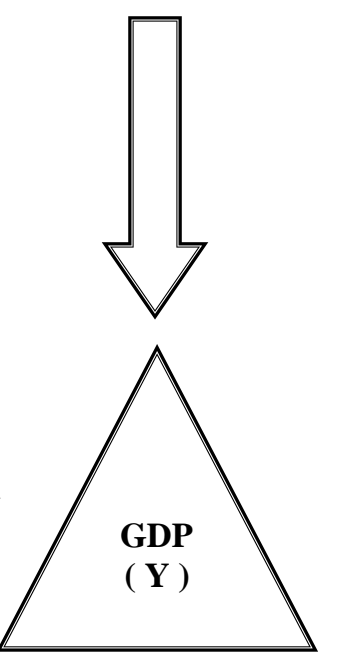

Gambar 2

Hubungan Penempatan Aset dalam Efektivitas Kebijakan Moneter 
Pemerintah berupaya untuk mencapai kestabilan perekonomian di sektor riil dengan kebijakan fiskal dan di sektor moneter dengan kebijakan moneter. Kebijakan fiskal yaitu dengan melakukan berbagai pengeluaran pemerintah guna mendorong perekonomian di sektor riil, sedangkan di sektor moneter BI menetapkan kerangka kebijakan moneter (ekspansif maupun kontraktif) untuk mencapai target perekonnomian yang sehat. Dalam kebijakan moneter, BI berupaya untuk mencapai operating target maupun intermediate target yang telah ditetapkan dengan menggunakan tools atau instrumen yang dipakai oleh Bank Indonesia untuk mencapai tujuan akhir atau goals. Otoritas Bank Sentral berada pada sektor moneter, sehingga perlu mekanisme khusus agar kebijakan moneter yang menggunakan instrumen penetapan suku bunga dapat ditransmisikan dari sektor moneter ke sektor riil/fiskal, yang disebut sebagai mekanisme transmisi kebijakan moneter. Efektivitas mekanisme transmisi kebijakan moneter tersebut tidak lepas pengaruhnya dari pola penempatan aset di masyarakat. Simpanan/tabungan di perbankan maupun pada lembaga keuangan lainnya merupakan jembatan penghubung (intermediate) sektor moneter dengan sektor riil di masyarakat. Oleh karena itu, pola penempatan aset di masyarakat memiliki peran yang cukup penting agar mekanisme transmisi kebijakan moneter berjalan dengan lancar mencapai target ekonomi di sektor riil.

\section{Penelitian Terdahulu}

Dalam penelitian sebelumnya yang dilakukan oleh Idris et al. (2002) berkenaan dengan mekanisme transmisi kebijakan moneter jalur harga aset, diketahui bahwa monetary shock yang ditransmisikan melalui portofolio aset finansial gagal dalam memengaruhi inflasi. Jalur harga aset dimana menggunakan harga stock sebagai proxy harga aset, tidak mencerminkan dengan baik kekayaan ekonomi. Hasil survey menunjukkan kurang dari 5 persen masyarakat yang menempatkan aset dalam bentuk stock, karena hal tersebut sistem transmisi tidak berjalan dengan lancar serta membutuhkan waktu yang panjang. Penelitian ini menyimpulkan perlunya data yang dapat dipercaya yang dapat mencerminkan kekayaan dan memiliki pengaruh yang erat dengan kebijakan moneter, sehingga benar-benar dapat berpengaruh terhadap kesejahteraan (welfare) masyarakat.

Di sisi lain menurut Astiyah et al. (2004) yang melakukan survei komposisi kepemilikan aset dan dampak kebijakan moneter terhadap kepemilikan aset menemukan bahwa sebagian besar dari responden masyarakat rumah tangga di Indonesia memiliki aset dalam bentuk fisik. Aset fisik dinilai masyarakat sebagai penempatan aset yang cukup aman saat terjadi fluktuasi ekonomi maupun inflasi. Ketika memiliki ekses likuiditas, masyarakat rumah tangga kecenderungan memiliki preferensi jenis aset fisik sebagai penempatannya. Dalam menempatkan dananya di Bank, responden rumah tangga tidak mempertimbangkan kondisi inflasi dalam menempatkan asetnya, karena responden masyarakat rumah tangga tidak memperhatikan pendapatan dari perubahan suku bunga simpanan di bank. 
Penelitian lainnya adalah yang dilakukan di Rusia oleh Andresen (2005) terkait dengan perilaku keuangan masyarakat rumah tangga dan persepsinya terhadap keamanan perbankan di Rusia. Andresen (2005) mengemukakan bahwa adanya ketidakpercayaan masyarakat dalam menempatkan asetnya di sektor keuangan. Karena ketika masyarakat menempatkan aset dalam di sektor keuangan, namun apabila terjadi devaluasi maka masyarakat akan mengalami kerugian, dan masyarakat menganggap hal ini sebagai penipuan. Hal ini yang menyebabkan masyarakat lebih percaya menempatkan asetnya untuk mengembangkan bisnis mereka sendiri.

Sedangkan menurut Koivu (2012) yang berfokus pada dampak kebijakan moneter terhadap harga aset dan konsumsi pada masyarakat rumah tangga di Cina menemukan bahwa Kebijakan moneter longgar (ease monetary policy) memang membawa harga aset meningkat di Cina. Selanjutnya konsumsi masyarakat rumah tangga di Kota memberi reaksi positif terhadap naiknya harga aset dan perumahan (residential), meskipun pengaruhnya sangatlah lemah. Kemungkinan memengaruhi rumah tangga oleh decisionmaking melalui kebijakan moneter sangat terbatas di Cina seperti lemahnya hubungan antara kebijakan moneter terhadap konsumsi. Penyebabnya adalah karena terbatasnya akses rumah tangga dalam sektor finansial. Sehingga agar kebijakan moeneter menjadi lebih efektif dalam perekonomian, perlunya liberalisasi dan perbaikan yang dibutuhkan dalam sektor finansial.

\section{METODA PENELITIAN}

\section{Populasi dan Sampel}

Populasi dalam penelitian ini adalah pedagang kecil dan menengah di Salatiga. Menurut Undang- Undang Nomor 20 Tahun 2008 tentang Usaha Mikro, Kecil dan Menengah (UMKM), kriteria untuk menggolongkan pedagang kecil yaitu berdasarkan omset pertahun> Rp300.000.000 - Rp2.500.000.000 atau Rp833.000 perhari. Namun karena tidak adanya data UMKM berdasarkan golongannya, maka ditetapkan yang menjadi responden adalah pedagang dengan minimum omset Rp600.000 perhari.

Data pedagang diperoleh dalam Salatiga dalam Angka dan Kecamatan dalam Angka 2012. Sampel dalam penelitian ini akan diambil melalui metoda Quota Sampling menurut data pedagang di tiap pasar di Kota Salatiga. Desain atau pendekatan penelitian yang digunakan yaitu cross-sectional dengan menggunakan proporsi binomial. Dengan derajad kepercayaan senilai 95 persen atau batas kesalahan 5 persen maka ditetapkan sampel yang dibutuhkan minimal sebanyak 123 sampel. Sehingga jumlah sampel yang dibagi menurut wilayah kecamatan di Salatiga yaitu: 
Tabel 3

Jumlah Sampel Menurut Wilayah Kecamatan di Salatiga

\begin{tabular}{lrrr}
\hline Kecamatan & Jumlah Pedagang & Distribusi Pedagang & Jumlah Sampel \\
\hline Argomulyo & 468 & $4,18 \%$ & 5 \\
Tingkir & 2.863 & $25,55 \%$ & 32 \\
Sidomukti & 3.268 & $29,17 \%$ & 36 \\
Sidorejo & 4.603 & $41,1 \%$ & 50 \\
\hline Total & 11.205 & $100 \%$ & 123 \\
\hline
\end{tabular}

\section{Jenis dan Sumber Data}

Penelitian ini menggunakan dua jenis sumber data, yaitu data primer yang diperoleh langsung dari responden dengan melakukan wawancara semi-terstruktur dengan bantuan kuesioner metoda kombinasi Close-ended dan Open-ended sebagai panduan. Data primer yang diperoleh pada penelitan ini meliputi: Karakteristik pedagang seperti jenis kelamin, usia, status perkawinan, dan latar belakang pendidikan, karakteristik usaha seperti jenis dagangan, lama berdagang, omset berdagang dan pengeluaran, serta penempatan aset seperti jenis-jenis aset yang dimiliki oleh pedagang dan pertimbangan-pertimbangan atau alasan-alasan pemilihan jenis aset tersebut dan data sekunder yang digunakan dalam penelitian ini adalah data PDRB Kota Salatiga maupun data jumlah pedagang di Kota Salatiga yang diperoleh dalam Profil Daerah Kota Salatiga tahun 2010 dan PDRB Kota Salatiga tahun 2011 dari publikasi BPS Kota Salatiga.

\section{Teknik Analisis Data}

Metoda analisis yang digunakan yakni statistik deskriptif dengan menggunakan data primer yang telah terkumpul, maka selanjutnya dilakukan analisis data secara sistematis berdasarkan data primer yang telah terkumpul yang kemudian menghasilkan informasi yang relevan.

\section{ANALISIS DAN PEMBAHASAN}

\section{Profil Responden}

Melihat hasil survei di lapangan, responden yang menjadi sampel dalam penelitian ini mayoritas merupakan wanita dan berusia antara 40-59 tahun sebanyak 95 pedagang. Dari hasil tersebut, karakter responden rata-rata merupakan ibu rumah tangga yang berusaha membantu suami dengan mencari tambahan penghasilan di sektor informal yakni sebagai pedagang.

Tabel 4

Profil Responden Berdasarkan Gender dan Usia

\begin{tabular}{lrrrr}
\hline Kelompok Umur & L & P & Total & Distribusi Kelompok Umur \\
\hline$<30$ tahun & - & 3 & 3 & $2,44 \%$ \\
$30-<40$ tahun & 5 & 24 & 29 & $23,58 \%$ \\
$40-<50$ tahun & 5 & 25 & 30 & $24,39 \%$ \\
$50-<60$ tahun & 12 & 31 & 43 & $34,96 \%$ \\
$\geq 60$ tahun & 6 & 12 & 18 & $14,63 \%$ \\
\hline Total & 28 & 95 & 123 & $100 \%$ \\
\hline
\end{tabular}


Apabila dilihat dari tingkat pendidikannya, responden yang memiliki pendidikan terakhir sampai ke jenjang Sekolah Menengah Atas (SMA) sebanyak 29,27 persen dari total keseluruhan responden. Namun fenomena yang cukup menarik yakni adanya tamatan sarjana yang berprofesi sebagai pedagang sebanyak 18,70 persen. Hal tersebut mengindikasikan beberapa hal, yakni bahwa tenaga kerja dengan latar belakang pendidikan sarjana tersebut telah memiliki kesadaran untuk berwirausaha, atau yang terjadi justru sebaliknya, yaitu mereka justru mengalami kalah persaingan sehingga tidak terserap di sektor formal dan terpaksa untuk bekerja di sektor informal.

Tabel 5

Profil Responden Berdasarkan Tingkat pendidikan

\begin{tabular}{|c|c|c|c|c|c|c|c|}
\hline $\begin{array}{c}\text { Tingkat } \\
\text { Pendidikan }\end{array}$ & $\begin{array}{c}<30 \\
\text { Tahun }\end{array}$ & $\begin{array}{c}30-<40 \\
\text { Tahun }\end{array}$ & $\begin{array}{c}40-<50 \\
\text { Tahun }\end{array}$ & $\begin{array}{c}50-<60 \\
\text { Tahun }\end{array}$ & $\begin{array}{c}\geq 60 \\
\text { Tahun }\end{array}$ & Total & $\begin{array}{c}\text { Distribusi } \\
\text { Tingkat } \\
\text { Pendidikan }\end{array}$ \\
\hline $\begin{array}{ll}\text { Tidak } & \text { Sekolah/ } \\
\text { tamat SD } & \end{array}$ & - & - & 4 & 6 & 2 & 12 & $9,76 \%$ \\
\hline Tamat SD & - & 3 & 8 & 18 & 3 & 32 & $26,02 \%$ \\
\hline Tamat SMP & - & 1 & 4 & 9 & 6 & 20 & $16,26 \%$ \\
\hline Tamat SMA & 2 & 13 & 7 & 8 & 6 & 36 & $29,27 \%$ \\
\hline Tamat Sarjana & 1 & 12 & 7 & 2 & 1 & 23 & $18,70 \%$ \\
\hline TOTAL & 3 & 29 & 30 & 43 & 18 & 123 & $100 \%$ \\
\hline
\end{tabular}

Dilihat dari jenis dagangannya, sebagian besar pedagang yang menjadi responden dalam penelitian ini merupakan pedagang sembako dan kelontong dimana dalam menjalankan usahanya ada yang menjual kelontong saja (21\%) atau sembako saja (25\%) seperti pada Diagram 1. Jenis dagangan ini menjadi jenis dagangan yang paling banyak karena sembako dan kelontong merupakan komoditas yang banyak dibutuhkan orang sehingga permintaan akan komoditas ini tinggi. 


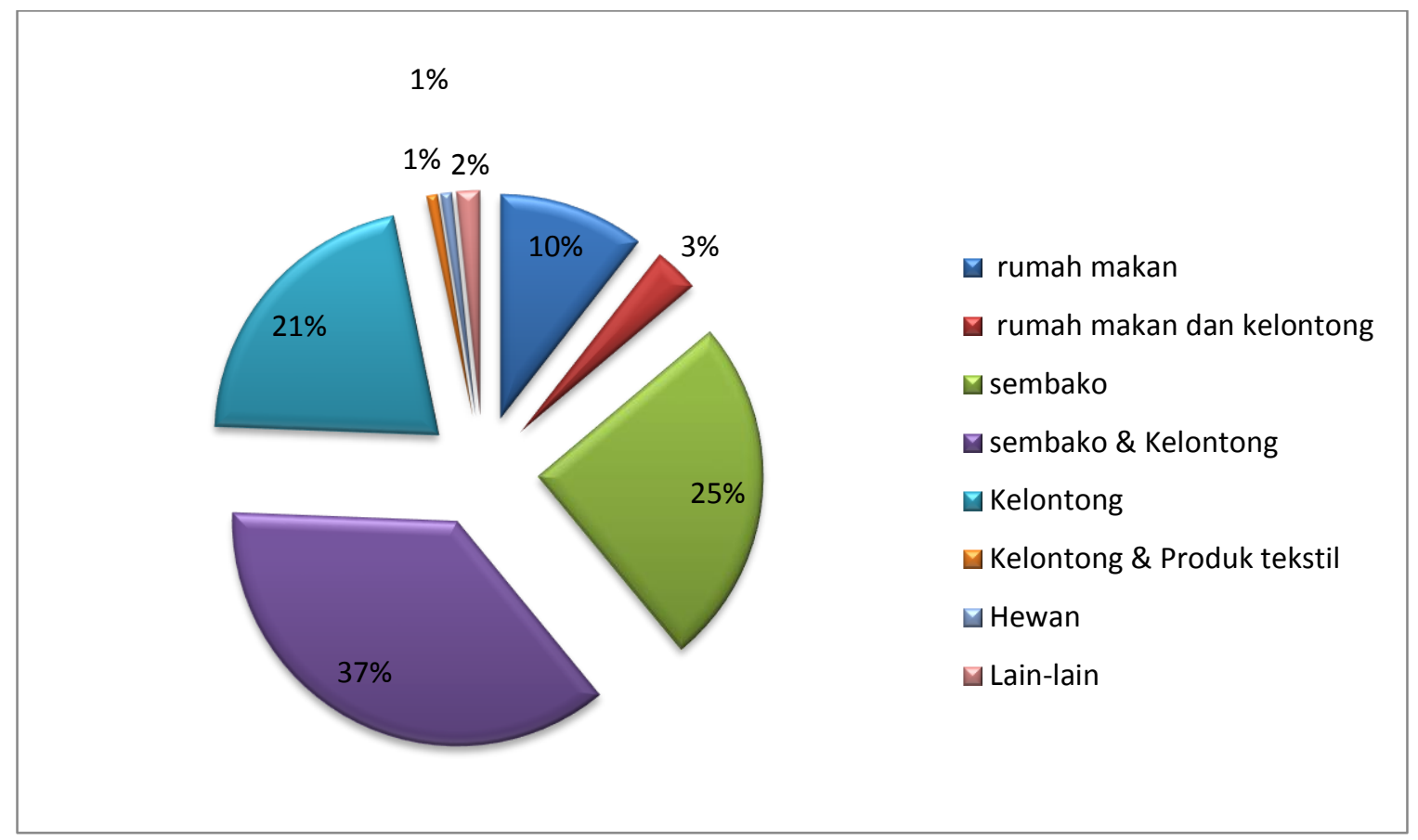

Gambar 1

Jenis Dagangan Responden

\section{Analisis Statistik Deskriptif}

\section{Statistik Deskriptif}

Tabel 6

Statistik Deskriptif

\begin{tabular}{lcrrrr}
\hline & N & Minimum & Maximum & Mean & Std. Deviation \\
\hline Tingkat_Pendidikan & 123 & 1 & 5 & 3,21 & 1,288 \\
Omset & 123 & 1 & 5 & 2,24 & 1,391 \\
Aset Tabungan & 123 & 1 & 2 & 1,07 & 0,261 \\
Aset Saham Obligasi & 123 & 2 & 2 & 2 & 0 \\
Aset Asuransi & 123 & 1 & 2 & 1,85 & 0,363 \\
Aset Kas Celengan & 123 & 1 & 2 & 1,97 & 0,178 \\
Aset Ternak & 123 & 1 & 2 & 1,87 & 0,338 \\
Aset Emas & 123 & 1 & 2 & 1,72 & 0,453 \\
Aset Tanah & 123 & 1 & 2 & 1,7 & 0,46 \\
Aset Bangunan & 123 & 1 & 2 & 1,76 & 0,426 \\
\hline Sum
\end{tabular}

Sumber: Data primer, 2013

Analisis data menggunakan variabel Dummy untuk keseluruhan variabel. Berdasarkan Tabel 6 variabel Tingkat_Pendidikan dan variabel Omset memiliki nilai maksimum ( $\max$ ) 5, sedangkan variabel Aset memiliki nilai maksimum (max) 2. Keseluruhan variabel memiliki nilai minimum (Min) 1 kecuali variabel Aset Saham Obligasi. Standard Deviasion menggambarkan penyimpangan data dari rata-rata hitungnya atau variabilitasnya. Berdasarkan tabel tersebut, penyimpangan data dari rata- 
rata hitungnya terbesar pada variabel Tingkat Pendidikan memiliki nilai Standard Deviasion 1,288 dan nilai terkecil Standard Deviasion pada variabel Aset Saham Obligasi yaitu 0.

\section{Analisis Pola Penempatan Aset Pedagang}

Penempatan aset merupakan usaha menyisihkan pendapatan (omset) rutin, yang kemudian dana tersebut disimpan untuk ditabung ataupun konsumsi bentuk barang tahan lama (durable goods). Menempatkan aset memiliki tujuan untuk memenuhi kebutuhan di masa depan yang memerlukan biaya cukup besar seperti kebutuhan tempat tinggal dan pendidikan anak, kesehatan, maupun dana untuk hari tua (pensiun). Tujuan yang lain yakni untuk investasi, dimana akan membantu ekspansi usaha maupun membantu menambah pendapatan yang dapat meningkatkan kesejahteraan. Tujuan yang terakhir yakni untuk berjaga-jaga, saat ada pengeluaran mendadak maka aset yang ada dapat membantu kekurangan likuiditas rumah tangga tersebut. Perilaku menempatkan aset tersebut akan memengaruhi efektivitas kebijakan moneter. Efektif atau tidaknya kebijakan moneter dalam memengaruhi sektor riil sangat bergantung terhadap pola dan perilaku penempatan aset masyarakat.

Dilihat dari kepemilikan aset responden (Diagram 2), menunjukkan bahwa responden tidak hanya memiliki 1 aset, bahkan memiliki lebih dari 3 aset. Responden yang memiliki 1 aset sebanyak 45 responden (36,59\%), sedangkan responden yang memiliki preferensi untuk menempatkan lebih dari 1 jenis aset sebanyak 78 responden $(63,41 \%)$. Responden yang memiliki aset lebih dari 3 tersebut mengkombinasikan aset keuangan seperti tabungan maupun asuransi dengan aset fisik seperti tanah dan bangunan. Kondisi ini sesuai dengan teori diversifikasi aset dimana adanya pepatah "jangan menaruh telur pada satu keranjang".

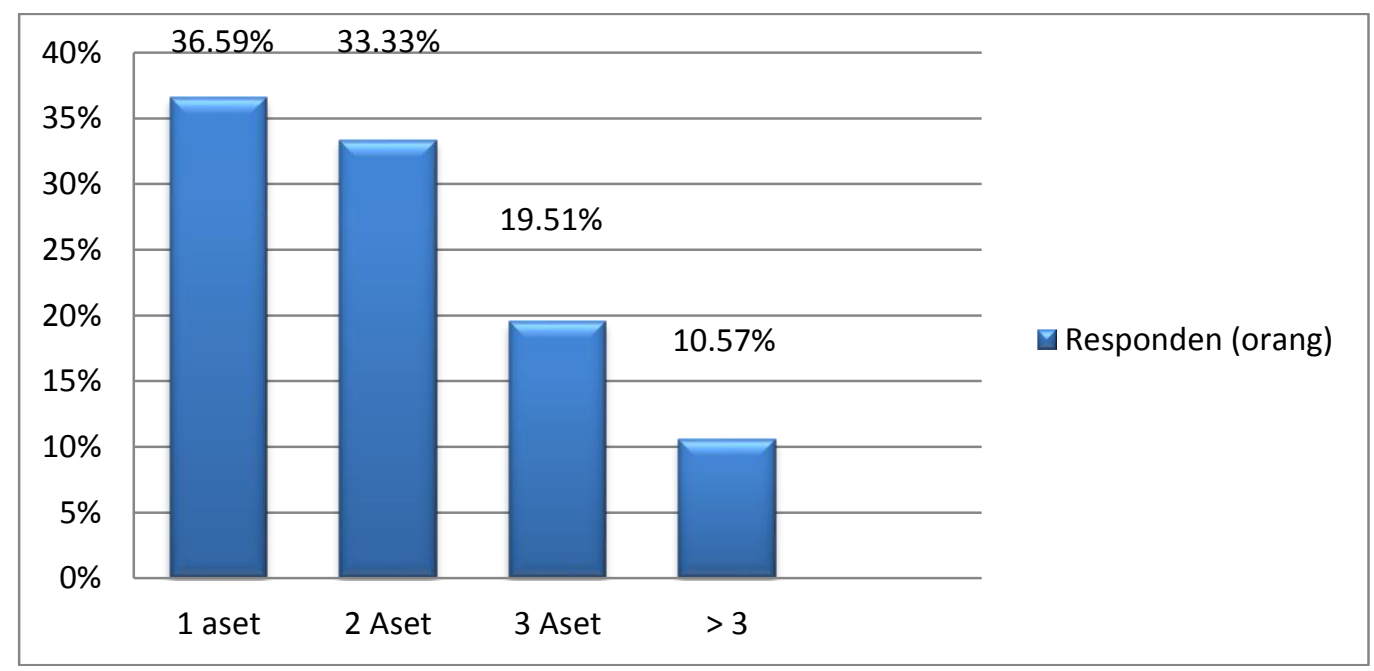

Gambar 2

Jumlah Kepemilikan Aset Responden 
Dalam hal penempatan aset, setiap individu mempunyai 2 jenis pilihan penempatan aset yakni penempatan pada aset keuangan dan atau pada penempatan aset fisik. Penempatan aset jenis keuangan dalam penelitian ini sebanyak 119 (96,75\%) responden, meliputi tabungan baik pada lembaga keuangan formal maupun non-formal, surat berharga seperti saham dan obligasi, asuransi, dan kas. Sedangkan aset jenis fisik sebanyak 75 responden (60,98\%), meliputi tanah, emas, bangunan, dan ternak.

Penempatan aset jenis keuangan masih lebih besar daripada penempatan aset jenis fisik karena aset jenis keuangan yakni seperti tabungan, tidak membutuhkan dana yang besar karena dapat menyisihkan sedikit demi sedikit. Berbeda dengan aset fisik, seperti jenis aset bangunan maupun tanah yang membutuhkan dana yang cukup besar.

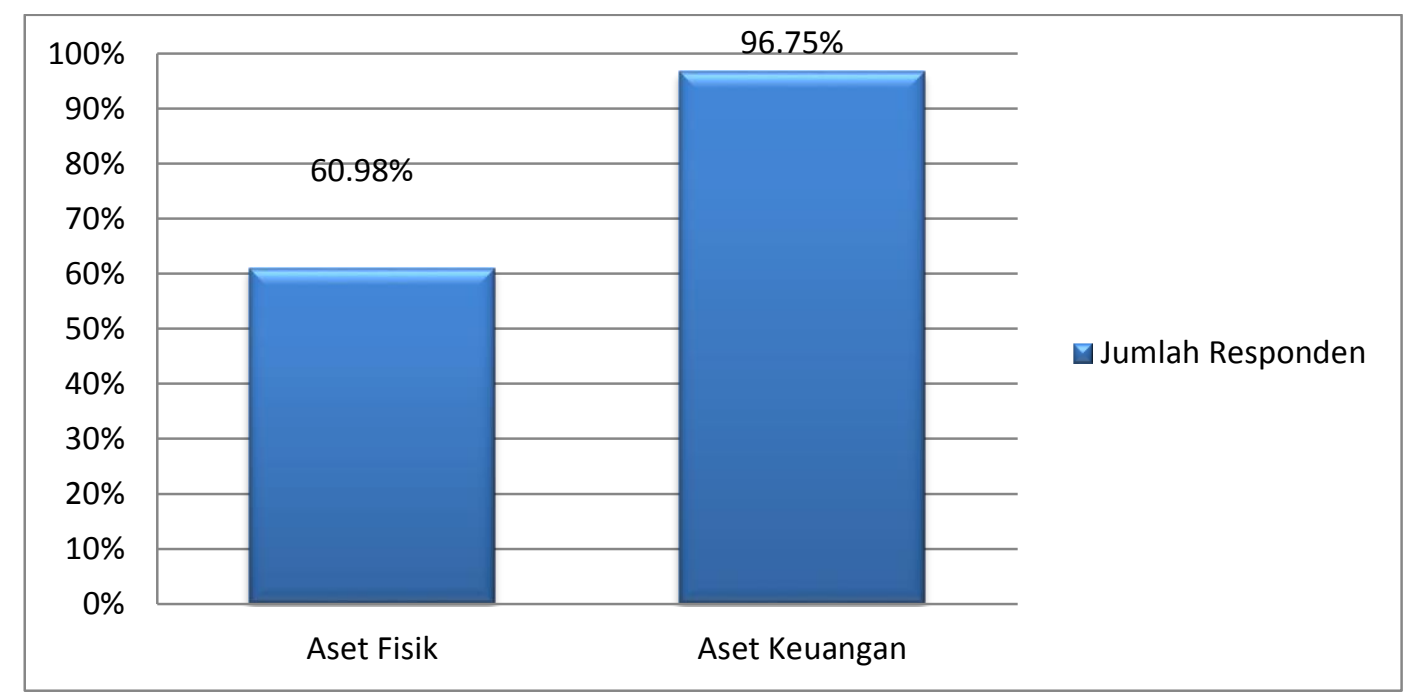

Gambar 3

Pola Penempatan Aset Berdasarkan Jenisnya

Apabila ditilik secara lebih mendalam, penempatan aset jenis keuangan dalam bentuk tabungan menjadi preferensi dominan responden. Tabungan yang ditempatkan pada lembaga keuangan formal sebanyak 92 responden $(74,80 \%)$ dan non-formal sebanyak 73 responden (59,35\%). Tabungan pada lembaga keuangan formal tersebut yakni seperti perbankan dan koperasi. 


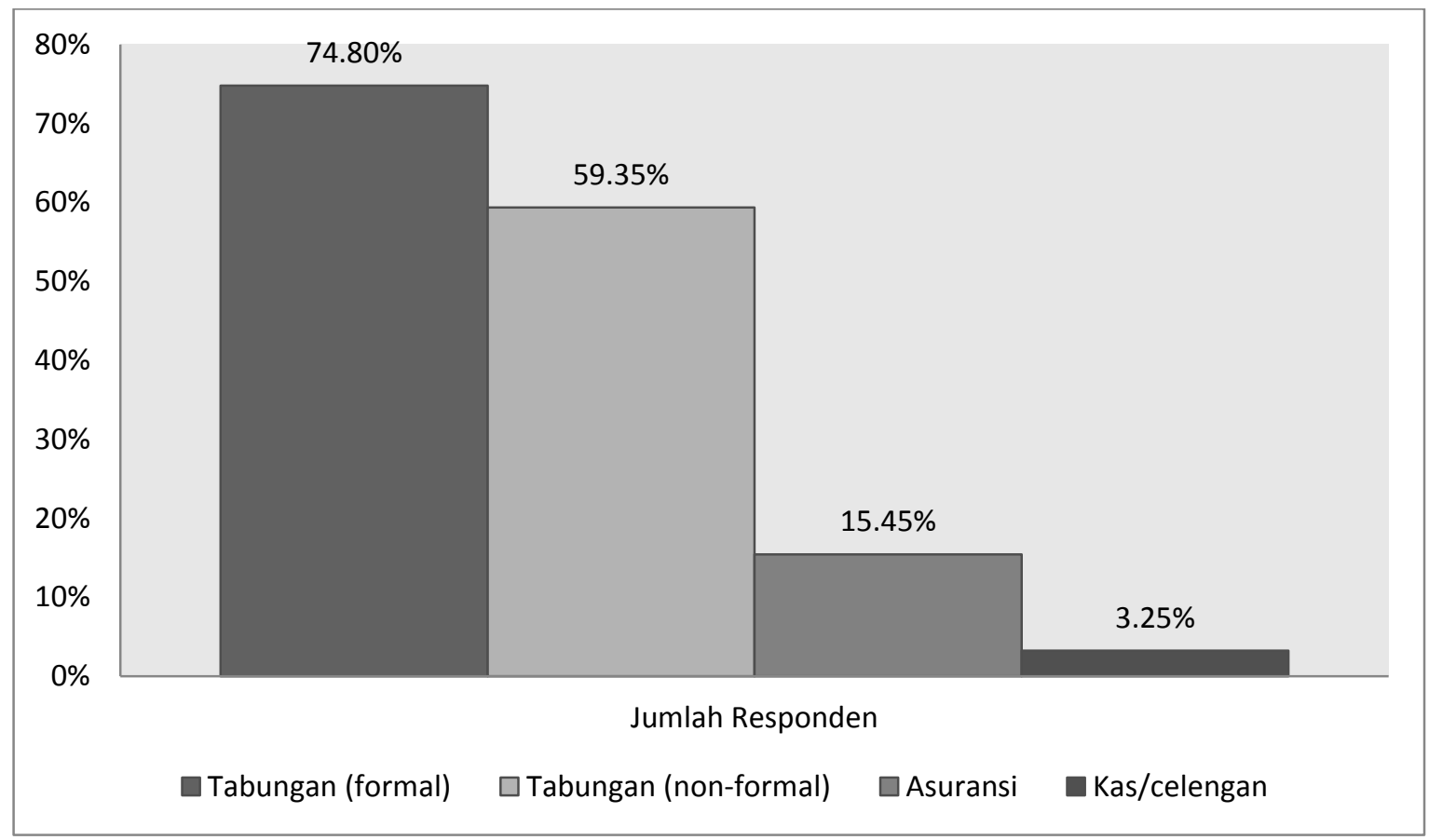

\section{Gambar 4}

Pola Penempatan Aset Keuangan

Pertimbangan utama responden menempatkan asetnya dalam bentuk tabungan khususnya pada lembaga keuangan formal karena faktor aman. Istilah aman yang dimaksud yakni aman dari kebocoran kas untuk pengeluaran rumah tangga sehari-hari selain aman dari faktor hilang. Dengan menempatkan tabungan di bank, simpanan yang ada tidak mudah bocor untuk alokasi pengeluaran. Faktor yang kedua yakni adanya motif berjaga-jaga. Seperti yang telah dikatakan sebelumnya, adanya kondisi ekonomi yang selalu berubah-ubah, adanya kebutuhan jangka panjang seperti biaya pendidikan anak serta kebutuhan lain yang perlu dipersiapkan jauh-jauh hari memengaruhi motif responden untuk berjaga-jaga di masa depan. Sedangkan faktor yang ketiga sebenarnya sedikit mirip dengan faktor kedua, yakni penggunaan di masa depan. Namun bedanya simpanan dialokasikan untuk mengembangkan usaha berdagang/permodalan responden agar dapat meningkatkan omset. Masih sedikit responden yang memanfaatkan perbankan untuk membantu lalu lintas pembayarannya ataupun transaksi bisnis.

Sementara itu tabungan pada lembaga keuangan non-formal yakni meliputi arisan RT/lingkungan tempat tinggal dan arisan pasar. Meskipun dana yang ditempatkan dalam bentuk arisan tersebut tidak begitu besar, namun sebanyak 73 responden $(59,35 \%)$ memilih menempatkan asetnya dalam bentuk tabungan arisan. Hal tersebut karena dipengaruhi oleh adanya faktor lingkungan di sekitar tempat tinggal responden dan berkaitan dengan norma sosial masyarakat. Responden menganggap arisan sebagai kegiatan sosial, untuk mempererat kerukunan antar masyarakat (pirukun).

Penempatan aset berupa kas atau celengan hanya 4 responden $(3,25 \%)$ saja. Responden ini memilih untuk menempatkan asetnya dalam bentuk kas yang biasanya 
ditempatkan dalam celengan di rumahnya sendiri. Menabung di bank hanya akan merugikan karena adanya potongan ditabungan mereka, anggapan tersebut yang menjadi pertimbangan responden sehingga lebih percaya dalam menempatkan tabungannya dalam bentuk kas untuk motif berjaga-jaga.

Responden yang menempatkan asetnya dalam bentuk asuransi yakni hanya 19 responden $(15,45 \%)$ dan yang lebih sedikit lagi bahkan tidak ada responden yang menempatkan asetnya berupa saham/obligasi. Hal tersebut mencerminkan bahwa asetaset keuangan seperti asuransi maupun surat-surat berharga masih belum banyak dikenal masyarakat. Baik asuransi maupun surat berharga membutuhkan dana yang tidak sedikit. Hasil serupa juga terdapat pada hasil survei yang dilakukan oleh Bank Indonesia (2004), dari 800 responden rumah tangga hanya $7,5 \%$ responden saja yang menempatkan asetnya dalam bentuk surat-surat berharga.

Bentuk aset fisik terdiri dari ternak, perhiasan atau emas, tanah yang berupa tanah kosong, sawah, ladang maupun kebun dan yang terakhir bangunan baik kios maupun rumah selain dari yang telah dimiliki responden sebelumnya (Diagram 5). Responden memiliki preferensi utama dalam menempatkan aset fisik berupa tanah sebanyak 37 responden (30,08\%). Responden menganggap dengan menempatkan asetnya berupa tanah responden akan mendapatkan keuntungan. Hal tersebut dikarenakan nilai jual tanah yang dari tahun ke tahun semakin melonjak, karena adanya fenomena kelangkaan dari ketersediaannya. Untuk itu investasi seperti aset tanah menjadi pertimbangan utama responden. Sementara itu faktor kedua yakni berkaitan dengan adanya penggunaan tanah sebagai lahan bercocok tanam maupun berkebun, yang kemudian menjadi sumber tambahan pendapatan bagi pedagang.

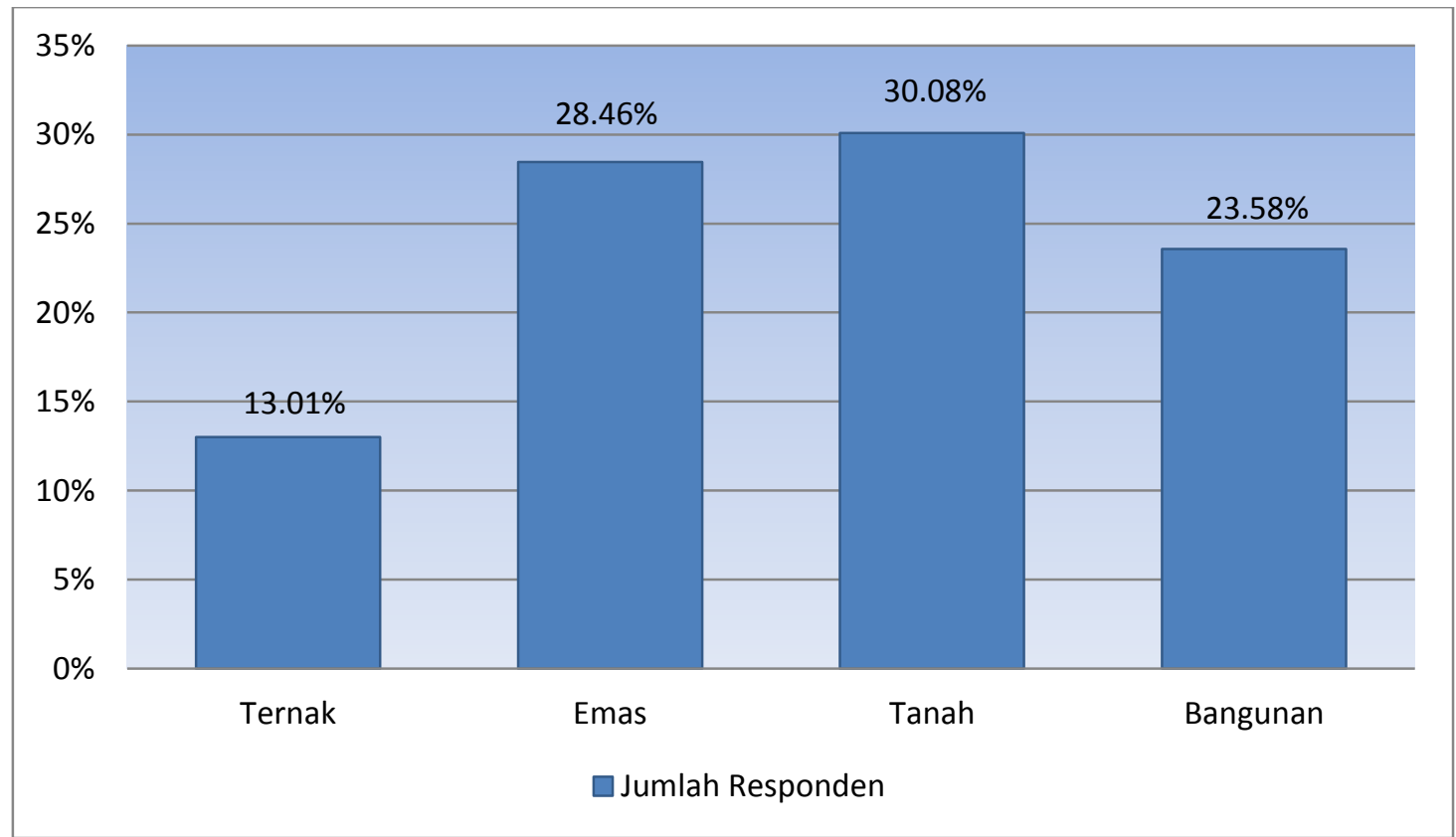

Gambar 5

Pola Penempatan Aset Fisik 
Aset jenis fisik berupa emas, menjadi preferensi setelah tanah sebanyak 35 responden $(28,46 \%)$ dalam menempatkan asetnya. Hal ini sesuai dengan profil responden dimana sebagian besar responden adalah wanita. Menurut anggapan responden, emas selain sebagai perhiasan yang dapat dipakai untuk memperindah seseorang maupun dengan tujuan gengsi, emas dapat menjadi fleksibel ketika suatu waktu ada kebutuhan mendesak. Terlebih lagi emas memiliki karakter yang mirip dengan aset seperti tanah, dimana nilai jualnya tidak mengalami penurunan, sehingga tidak akan mengalami kerugian dengan menyimpan aset berupa emas. Sehingga emas memiliki nilai ganda selain sebagai aset, namun juga dapat menjadi perhiasan untuk dipakai.

Aset fisik berupa bangunan menempati urutan ketiga yang dimiliki oleh 29 $(23,58 \%)$ responden. Tidak hanya aset berupa emas yang memiliki karakter seperti aset tanah, sama halnya dengan bangunan. Namun bukan berkaitan dengan faktor harga jual yang terus merangkak naik, namun berkaitan dengan kegunaan atau utilitasnya. Aset ini lebih banyak digunakan untuk menambah usaha lain yang dapat meningkatkan pendapatannya seperti menyewakan kos dan kontrakan. Adanya lokasi yang menguntungkan dimana berdekatan dengan kampus menjadikan usaha tersebut sebagai lahan subur untuk menambah pendapatan. Selain itu, yang menjadi pertimbangan responden untuk menempatkan asetnya berupa bangunan yakni, untuk mengembangkan usahanya (berdagang) menjadi lebih besar lagi dengan membangun kios cabang ataupun fasilitas penunjang seperti gudang.

Aset fisik yang terakhir yakni berupa ternak hanya menjadi preferensi sebanyak 16 responden $(13,01 \%)$. Pertimbangan responden yakni apabila suatu waktu ada kebutuhan mendadak maka dapat flesksibel untuk digunakan untuk konsumsi ataupun dijual.

Apabila ditinjau dari hubungan penempatan aset dengan omset pedagang, maka mengindikasikan bahwa adanya kesamaan pola di dalam penempatan aset dalam berbagai bentuknya. Namun ada hal yang menonjol terlihat pada aset dalam bentuk asuransi. Pola penempatan aset pada asuransi mengindikasikan adanya hubungan searah antara omset responden dengan penempatan asetnya. Pada Tabel 7 menunjukkan bahwa semakin besar omsetnya, maka proporsi penempatan aset dalam bentuk asuransi semakin meningkat pula. Dengan kata lain besarnya omset pedagang memiliki pengaruh pada penempatan aset dalam bentuk asuransi. Omset yang dimiliki oleh pedagang berpengaruh akan kemampuan responden dalam membayar premi asuransi yang membutuhkan dana tidak sedikit. 
Tabel 7

Hubungan Penempatan Aset dengan Omset Pedagang

\begin{tabular}{|c|c|c|c|c|c|}
\hline $\begin{array}{c}\text { Omset } \\
\text { Berdagang } \\
\text { (per bulan) }\end{array}$ & $\begin{array}{l}\text { Rp } 18 \text { Juta - } \\
<\text { Rp } 30 \text { Juta }\end{array}$ & $\begin{array}{l}\text { Rp } 30 \text { Juta - } \\
<\text { Rp } 60 \text { Juta }\end{array}$ & $\begin{array}{l}\text { Rp } 60 \text { Juta - } \\
<\text { Rp } 90 \text { Juta }\end{array}$ & $\begin{array}{l}\text { Rp } 90 \text { Juta - } \\
<\text { Rp } 120 \text { Juta }\end{array}$ & $\geq 120$ Juta \\
\hline Tabungan & $96,1 \%$ & $84,4 \%$ & $87,5 \%$ & $100 \%$ & $100 \%$ \\
\hline Asuransi & $11,8 \%$ & $12,5 \%$ & $12,5 \%$ & $12,5 \%$ & $37,5 \%$ \\
\hline Kas/celengan & $2,0 \%$ & $6,3 \%$ & $6,3 \%$ & $0 \%$ & $0 \%$ \\
\hline Ternak & $7,8 \%$ & $15,6 \%$ & $12,5 \%$ & $25,0 \%$ & $18,8 \%$ \\
\hline Emas & $31,4 \%$ & $21,9 \%$ & $18,8 \%$ & $37,5 \%$ & $37,5 \%$ \\
\hline Tanah & $25,5 \%$ & $21,9 \%$ & $37,5 \%$ & $62,5 \%$ & $37,5 \%$ \\
\hline Bangunan & $33,3 \%$ & $15,6 \%$ & $0 \%$ & $37,5 \%$ & $25,0 \%$ \\
\hline
\end{tabular}

Sumber: Data primer, 2013

Begitu juga halnya dengan hubungan antar penempatan aset dengan tingkat pendidikan responden, aset bentuk asuransi menunjukkan sesuatu yang menonjol dibandingkan dengan bentuk aset lainnya. Latar belakang pendidikan memiliki pengaruh yang positif akan penempatan aset dalam bentuk asuransi. Hal tersebut dapat terlihat dari Tabel 7 dimana proporsi pedagang yang menempatkan asetnya dalam bentuk asuransi meningkat seiring dengan latar belakang pendidikannya.

Tabel 8

Hubungan Penempatan Aset dengan Tingkat Pendidikan Responden

\begin{tabular}{lrrrrr}
\hline $\begin{array}{c}\text { Tingkat } \\
\text { Pendidikan }\end{array}$ & $\begin{array}{c}\text { Tidak } \\
\text { Sekolah/tamat } \\
\text { SD }\end{array}$ & $\begin{array}{c}\text { Tamat } \\
\text { SD }\end{array}$ & $\begin{array}{c}\text { Tamat } \\
\text { SMP }\end{array}$ & $\begin{array}{c}\text { Tamat } \\
\text { SMA }\end{array}$ & $\begin{array}{c}\text { Tamat } \\
\text { Sarjana }\end{array}$ \\
\hline Tabungan & $100 \%$ & $87,5 \%$ & $95,0 \%$ & $88,9 \%$ & $100 \%$ \\
Asuransi & $0 \%$ & $12,5 \%$ & $15,0 \%$ & $16,7 \%$ & $26,1 \%$ \\
Kas/celengan & $0 \%$ & $6,3 \%$ & $0 \%$ & $5,6 \%$ & $0 \%$ \\
Ternak & $8,3 \%$ & $12,5 \%$ & $20,0 \%$ & $8,3 \%$ & $17,4 \%$ \\
Emas & $41,7 \%$ & $25,0 \%$ & $20,0 \%$ & $25,0 \%$ & $39,1 \%$ \\
Tanah & $50,0 \%$ & $31,3 \%$ & $20,0 \%$ & $22,2 \%$ & $39,1 \%$ \\
Bangunan & $16,7 \%$ & $25,0 \%$ & $30,0 \%$ & $19,4 \%$ & $26,1 \%$ \\
\hline Sumber: Data primer, 2013 & & & & &
\end{tabular}

Meskipun jenis aset keuangan seperti tabungan telah mengalami persebaran yang cukup merata di berbagai tingkat pendidikan responden, namun sebagian besar responden tidak memiliki pengetahuan akan variabel moneter seperti suku bunga maupun inflasi. Hanya sebanyak 17 responden (14\%) yang memiliki pengetahuan akan suku bunga maupun inflasi, sedangkan sisanya 106 responden (86\%) responden tidak memiliki pengetahuan mengenai suku bunga maupun inflasi. 


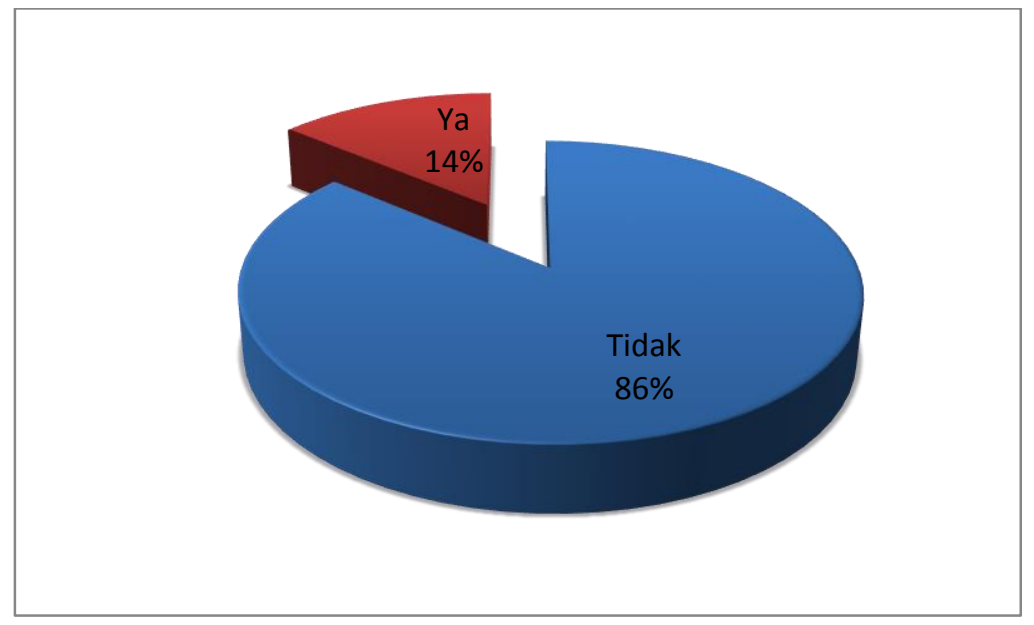

Gambar 6

Pengetahuan Responden terhadap Variabel Moneter

Dari responden yang memiliki pengetahuan mengenai suku bunga maupun inflasi, sebanyak 8 responden $(6,5 \%)$ memiliki tingkat pendidikan tamat sarjana. Namun ada pula sebanyak 15 responden $(12,2 \%)$ yang memiliki tingkat pendidikan tamat sarjana pun tidak memahami suku bunga maupun inflasi. Hal tersebut menunjukkan sedikitnya masyarakat yang memiliki pengetahuan akan variabel moneter seperti inflasi dan suku bunga. Oleh karena itu, berdampak pada berbagai aktivitas penempatan aset yang ada tidak didasarkan oleh pengetahuan variabel moneter, dan kurangnya perhatian masyarakat akan berbagai fenomena moneter yang terjadi, baik seperti naik turunnya tingkat inflasi maupun tingkat suku bunga. Hal tersebut dapat menyebabkan munculnya kondisi inelastis antara suku bungan dengan jumlah uang beredar di masyarakat.

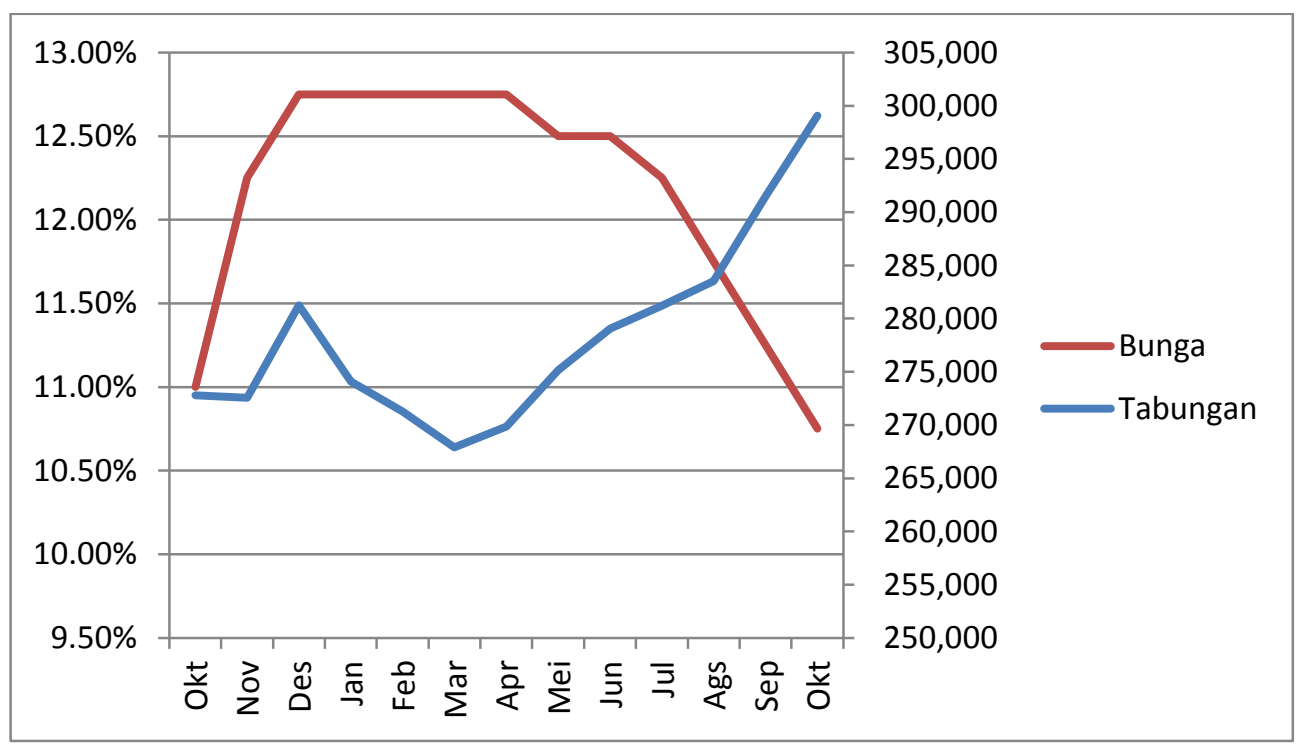

Gambar 7

Hubungan BI Rate dengan Nilai Tabungan Masyarakat di Perbankan (Miliar Rupiah) 
Berdasarkan Diagram 7 BI rate mengalami perubahan yang signifikan sejak Oktober 2005 hingga Oktober 2006 sebagai dampak kenaikan tingkat inflasi yang disebabkan oleh kenaikan harga BBM (Administered Price). Selama periode satu tahun tersebut BI Rate telah mengalami perubahan baik peningkatan maupun penurunan 200 basis points. Namun peningkatan BI Rate tersebut tidak dimanfaatkan masyarakat guna mendapatkan profit atau keuntungan dari pendapatan bunga tabungan/simpanan di Bank. Grafik tersebut menggambarkan selama kenaikan BI Rate dari bulan Oktober 2005-bulan April 2006, nilai tabungan/simpanan masyarakat di perbankan justru memiliki trend yang menurun, meskipun pada bulan Desember 2005 mengalami peningkatan. Sebaliknya ketika BI Rate mulai bergerak turun pada Bulan Mei 2006, nilai tabungan dimasyarakat justru mengalami peningkatan. Secara umum selama periode tersebut, tingkat bunga tidak berpengaruh pada nilai simpanan/tabungan dimasyarakat. Dengan kata lain perubahan tingkat BI Rate tidak dapat memengaruhi jumlah uang yang beredar di masyarakat untuk menempatkan asetnya dalam bentuk simpanan/tabungan di perbankan.

\section{SIMPULAN, KETERBATASAN DAN SARAN}

Dari hasil pembahasan tersebut, maka dapat disimpulkan bahwa sebagian besar pedagang memiliki lebih dari satu jenis aset. Berdasarkan jenisnya, penempatan aset jenis keuangan lebih diminati oleh pedagang dibandingkan dengan menempatkan asetnya dalam bentuk aset jenis fisik. Hal tersebut karena aset keuangan tidak membutuhkan dana yang besar, karena dapat disisihkan sedikit demi sedikit, sedangkan aset fisik membutuhkan dana yang cukup besar.

Aset jenis keuangan berupa tabungan pada lembaga keuangan formal menjadi preferensi dominan penempatan aset oleh pedagang di Kota Salatiga. Disusul berturutturut oleh penempatan aset bentuk tabungan pada lembaga keuangan non-formal, asuransi dan yang terakhir penempatan kas. Tidak ada satu pun dari pedagang yang menempatkan asetnya dalam bentuk surat berharga seperti saham dan obligasi. Pilihan penempatan aset jenis fisik, penempatan dalam bentuk tanah menjadi prioritas preferensi dari pedagang. Pilihan berikutnya emas, bangunan, dan yang terakhir ternak. Sebagian besar dari pedagang tidak memiliki pengetahuan akan variabel moneter seperti tingkat bunga maupun inflasi. Sehingga dalam penempatan asetnya tidak didasarkan pada pengetahuan moneter.

Dengan adanya kenyataan bahwa sebagian besar dari pedagang di Salatiga dalam menempatkan asetnya tidak didasarkan oleh pengetahuan variabel moneter seperti tingkat bunga dan inflasi namun karena faktor kebiasaan, dalam hal ini perilaku pedagang kurang peka akan fenomena moneter. Hal tersebut menyebabkan kondisi hubungan inelastis antara tingkat bunga dengan jumlah uang beredar, sehingga kebijakan moneter dalam rangka pengendalian jumlah uang beredar dengan menggunakan instrumen tingkat bunga menjadi tidak efektif. Dengan melalui pengenalan dini di berbagai Sekolah Dasar dengan 
kerjasama dengan berbagai bank umum. Bank umum diharapkan dapat memberikan pengenalan financial literacy melalui berbagai kegiatan arisan di masyarakat.

Penelitian ini hanya mampu menganalisis perilaku masyarakat dalam menempatkan asetnya pada satu profesi masyarakat saja yakni pedagang. Responden dalam penelitian pun belum dapat menjangkau dari berbagai tingkat kelas masyarakat yang ada di Kota Salatiga, sehingga belum dapat memproyeksikan perilaku masyarakat secara umum di Kota Salatiga. Penelitian selanjutnya diharapkan dapat menganalisis di semua profesi masyarakat dan dapat mewakili berbagai tingkat kelas masyarakat di Kota Salatiga secara proporsional.

\section{DAFTAR PUSTAKA}

Andresen, Nils August. 2005. "As safe as the bank? Household financial behaviour and economic reasoning in post-Soviet Russia."

Astiyah, Siti, Clarita Ligaya, Retno Muhardini, Rendra Z Idris, dan MA Majid Ikram. 2004. "Komposisi kepemilikan aset dan dampak kebijakan moneter terhadap kepemilikan aset: Hasil survei." Buletin Ekonomi Moneter dan Perbankan 7 (1): $1-40$.

Idris, Rendra Z., Tri Yuniarti, Clarita L. Iskandar, dan Darsono. 2002. Asset price channel of monetary transmission in Indonesia. Jakarta: Bank Indonesia.

Koivu, Tuuli. 2012. "Monetary policy, asset prices and consumption in China." Economic Systems 36 (2): 307-25. https://doi.org/10.1016/j.ecosys.2011.07.001.

Mishkin, Frederic S. 2004. The economics of money, banking, and financial markets. Pearson Addison Wesley. https://doi.org/10.1017/CBO9781107415324.004.

Nopirin. 2000. Ekonomi Moneter. 4ed. Yogyakarta: BPFE UGM.

Pohan, Aulia. 2008. Kerangka kebijakan moneter dan implementasinya di Indonesia. Jakarta: Rajawali Pers. 